\title{
Energy Storage Systems for Hybrid Electric Vehicles - New Concept of Motorization
}

\begin{abstract}
Introduction
Significant attention has recently been given to development of new, improved energy storage devices, with respect to their applications in automotive market. Several, so-called "hybrid electric vehicle" (HEV ${ }^{1}$ ) systems have been fully commercialized over the past couple of years (e.g. Toyota Prius, Honda Insight and Civic HEVs). In addition to that, considerable interest was developed in research on pure electric vehicle (EV), as well as on hybrid fuel cell-powered vehicle (HFCV) systems (e.g. by Daimler-Chrysler, Toyota and Ford Motor Companies).

One of the major factors that influenced development of new vehicle systems was a concern about the environmental consequences of fossil fuel use for propulsion of vehicles. Another considered aspect was close dependence of industrialized countries on shrinking oil reserves and continuous oscillation of oil price. HEVs currently attract a great deal of attention, due to their ability to save fuel and reduce emissions. They are also perceived as transitional vehicles on the move to an ultimate, zero emission solution, fuel cell (FC)-powered system [1-3].
\end{abstract}

\section{The Hybrid Electric Vehicle System}

Numerous fuel cell-powered vehicle prototypes have been built so far, based on various fuel cell configurations (PEMFC, DMFC, SOFC). However, low temperature fuel cell technology involves application of expensive electrode catalyst materials, such as $\mathrm{Pt}$ and $\mathrm{Pt} / \mathrm{Ru}$ alloys, and expensive fuels (pure $\mathrm{H}_{2}$ or methanol). On the other hand, high temperature (SOFC or MCFC) systems allow for high efficiency

1022 Gordon Heights, Milton, Ontario, Canada, L9T 5S9.

I The HEV system is based on a combination of a powerful electric motor with an auxiliary combustion engine, where fuel consumption for such-powered a vehicle is significantly reduced, as compared with a conventional combustion engine system. 
autothermal conversion of hydrocarbons (usually $\mathrm{CH}_{4}$ ) to $\mathrm{H}_{2}$. However, at operational temperatures reaching $700-900^{\circ} \mathrm{C}$, selection of proper material becomes a serious challenge, due to possible material degradation, problems with sealing and incompatibility of the thermal expansion properties. For all the reasons given above, commercialization of the fuel cell-powered vehicles (especially for small, passenger type cars) is probably quite remote.

On the other hand, hybrid electric vehicles offer extension of the internal combustion engine (ICE) technology into a pro-ecological, low fuel consumption EV-ICE hybrid design. "Electrified" vehicles are typically equipped with packages of high voltage, nickel metal-hydride batteries, which can additionally be supplemented by a supercapacitor device, in order to power the electric engine of the hybrid power unit.

\section{Nickel Metal-Hydride Batteries - Low Temperature Performance}

The rechargeable nickel metal-hydride battery $(\mathrm{NiMH})$ has a similar design to that of nickel cadmium battery ( $\mathrm{NiCd}$ ). The principal difference is that the former uses hydrogen absorbed in a metal alloy for the active negative material, in place of cadmium in the latter one. The active material of the positive electrode of the NiMH battery is nickel oxyhydroxide $(\mathrm{NiOOH})$, in the charged state. The negative active material in the charged state is hydrogen, in the form of a metal hydride.

In general, there are two types of metal hydride alloys: $\mathrm{AB}_{2}(\mathrm{Ti} / \mathrm{Zr}-$ based) and $\mathrm{AB}_{5}$ (rare earth or Misch metal-based compositions). Among those of $\mathrm{AB}_{5}$.type, most materials are derived from the $\mathrm{LaNi}_{5}$ family. Misch metal-based materials provide charge capacity of $230-310 \mathrm{mAh} / \mathrm{g}$ of active mass, have excellent rate capability and cycle life [3, 4]. Typical $\mathrm{NiMH}$ battery packages for HEV applications consist of several dozens of single units (e.g. 6.5Ah/7.2V, six-cell prismatic module by Panasonic), connected in series to form high voltage power systems.

Generally, at room temperature, NiMH battery capacity can be fully extracted, under a wide range of discharge rates $\left(\mathrm{C}^{2} / 10<\mathrm{i}<10 \mathrm{C}\right)$ and recharge of the battery can be completed in a short period of time (e.g. $30 \mathrm{~min})$. However, both the discharge and charge characteristics of the battery are temperature-dependent. The discharge performance severely deteriorates at temperatures below $-20^{\circ} \mathrm{C}$. This phenomenon becomes especially important when attempting to start a vehicle at low ambient temperatures. There, accessible battery capacity could become as low as 10 to $20 \%$ of the nominal value and is strongly dependent on the rate of the

2 C- Nominal capacity of the battery, [Ah]. 
discharge process. Thus, improvement of low temperature performance of the nickel metal-hydride battery for vehicular applications became one of the most important problems for this energy storage system.

Although reaction resistances for positive and negative electrodes are comparable at room temperature, at low (negative) temperatures, the reaction resistance caused by the negative electrode (see e.g. ref. 5) dramatically increases (an order of magnitude). Thus, improvement of the battery performance at low temperatures can practically be realized through reducing the reaction resistance of the negative (metal-hydride) electrode.

During the charging process (discharge proceeds in a reversed sequence of reactions), the metal-hydride alloy undergoes a reversible $\mathrm{H}$ absorbingdesorbing reaction, as in a sequence of reaction steps (1-5) below:

$$
\begin{aligned}
& H_{2} O_{(\text {Bulk })} \Rightarrow H_{2} O_{(\text {Surf })} \\
& M+H_{2} O_{(\text {Sur })}+e^{-} \Rightarrow M H_{O P D}^{a d s}+O H_{(\text {Sur })}^{-} \\
& O H_{(\text {Sur })}^{-} \Rightarrow O H_{(B u k)}^{-} \\
& M H_{O P D}^{a d s} \Rightarrow M H_{\text {Sur }}^{a b s}(x=0) \\
& M H_{S_{u r}}^{a b s}(x=0) \Rightarrow M H_{\text {Bulk }}^{\text {abs }}(x=L)
\end{aligned}
$$

As pointed out by some authors [6-11], the performance of a metalhydride electrode is determined by two major factors: the diffusion of absorbed $\mathrm{H}$ from the bulk to the electrode surface (reversed step 5) and the kinetics of the charge-transfer reaction (step 2 above). Some role may also be played by the $\mathrm{H}$ transfer from the adsorbed to absorbed state (step 4). The electrode's discharge capacity will then strongly depend on the rate of its discharge. Diffusion of $\mathrm{H}$ and the process of electron transfer are temperature dependent. Thus, at low temperatures (e.g. $<-20^{\circ} \mathrm{C}$ ), the performance of $\mathrm{MH}$ electrode may significantly decline, leading to reduction of its original capacity at corresponding rates, at room temperature. Moreover, at low temperatures, there are other important factors to be considered, such as changes in the solution conductivity/ionic and molecular mobilities, local ionic concentration gradients built during the dis(charge) process within the porous structure, etc. All these elements may significantly contribute to the performance of the NiMH battery at low temperatures.

\section{1. Materials and a.c. impedance experimental procedures}

$\mathrm{MH}$ electrodes for high power applications can be prepared from a typical $\mathrm{AB}_{5}$ - type of metal-hydride alloy (Misch metal alloy), with addition of conductive additives and binders. Some metal powders (e.g. 
$\mathrm{Co}, \mathrm{Mo}, \mathrm{Cu}, \mathrm{Ni}$, etc.), prepared to critical specifications, can also be added as catalytic additives to the $\mathrm{MH}$ electrode mass. Content of all auxiliary additives is typically about $5-10 w t . \%$ of the total electrode mass.

Electrochemical a.c. impedance experiments are usually performed in an aqueous $6.0 \mathrm{M} \mathrm{KOH}$ solution (similar to that of the battery electrolyte), where an electrochemical cell is made of Teflon, or similar material. A typical system used for impedance measurements consists of Solartron 1255 Frequency Response Analyser (FRA) and 1287 Electrochemical Interface (EI). Instruments are controlled by ZPlot software for Windows (Scribner Associates, Inc.). The generator provides an output signal of known amplitude $(5 \mathrm{mV})$ and the frequency range is typically swept between $20 \times 10^{3}$ to $1 \times 10^{-3} \mathrm{~Hz}$. Data analysis is performed with ZView software, where the impedance spectra are fitted by means of a complex, non-linear, least-squares immitance fitting program, $L E V M$, written by J. Ross Macdonald in ref.12.

\section{2. A.c. impedance characterization of $M H\left(A B_{s}\right.$-type) electrodes in $6 \mathrm{M} \mathrm{KOH}$ solution}

Typical a.c. impedance behaviour of the $\mathrm{MH}$ electrode in $6 \mathrm{M} \mathrm{KOH}$ at room temperature (RT) and ca. $50 \% \mathrm{SOC}^{3}$, in the absence and presence of a catalytic metal powder, is shown in Figures $1 \mathrm{a}$ and b below. It can be noted there (Figure 1a) that addition of metal powder (in the amount of several wt.\%) into the $\mathrm{MH}$ electrode mass has a significant impact on reduction of the reaction charge-transfer resistance $\left(R_{t}\right)$. For a system containing metal powder (curve $B$ in Figure $1 b$ ), one can also distinguish a high-frequency semicircle, corresponding to the contact resistance and capacitance between the current collector and the $\mathrm{MH}$ alloy pellet $\left(\mathrm{R}_{\mathrm{col}}\right.$, $\mathrm{C}_{\text {col }}$ ), as well as the hydrogen diffusion Warburg impedance line, at the low frequency end.

The semicircles observed in Figure 1 are depressed (see also Figure 2 for comparison), which is a characteristic behaviour for a porous-type electrode system $[11,13]$. The above could be explained in terms of a frequency dispersion of the interfacial capacitance, which may also be influenced by specific adsorption of ions. This requires a constant phase element (CPE) to be used during the fitting of experimental impedance data.

The corresponding impedance behaviour of the $\mathrm{MH}$ electrodes at $25^{\circ} \mathrm{C}$ is shown in Figures $2 \mathrm{a}$ and $\mathrm{b}$ below. Here, again, the effect of metal powder addition into the $\mathrm{MH}$ electrode mass is expressed by significant reduction of the $R_{t}$ parameter (compare curve $B$ with curve $A$ in Figure 2a). The hydrogen diffusion line is not observed at $-25^{\circ} \mathrm{C}$, which is likely

SOC- state of charge. 
due to the frequency limitation of equipment used $\left(10^{-3} \mathrm{~Hz}\right)$. Also, the temperature effect on the measured $R_{t}$ parameter is clearly noticeable in the Nyquist spectra (compare Figure 1a with 2a).

From the complex analysis of the charge-transfer $R_{t}$ parameter, at various SOCs, it could be concluded that the catalytic effect of metal powder additive is most significant at highly discharged electrodes (based on $R_{t}(A) / R_{t}(B)$ ratio in Figure 3 ).
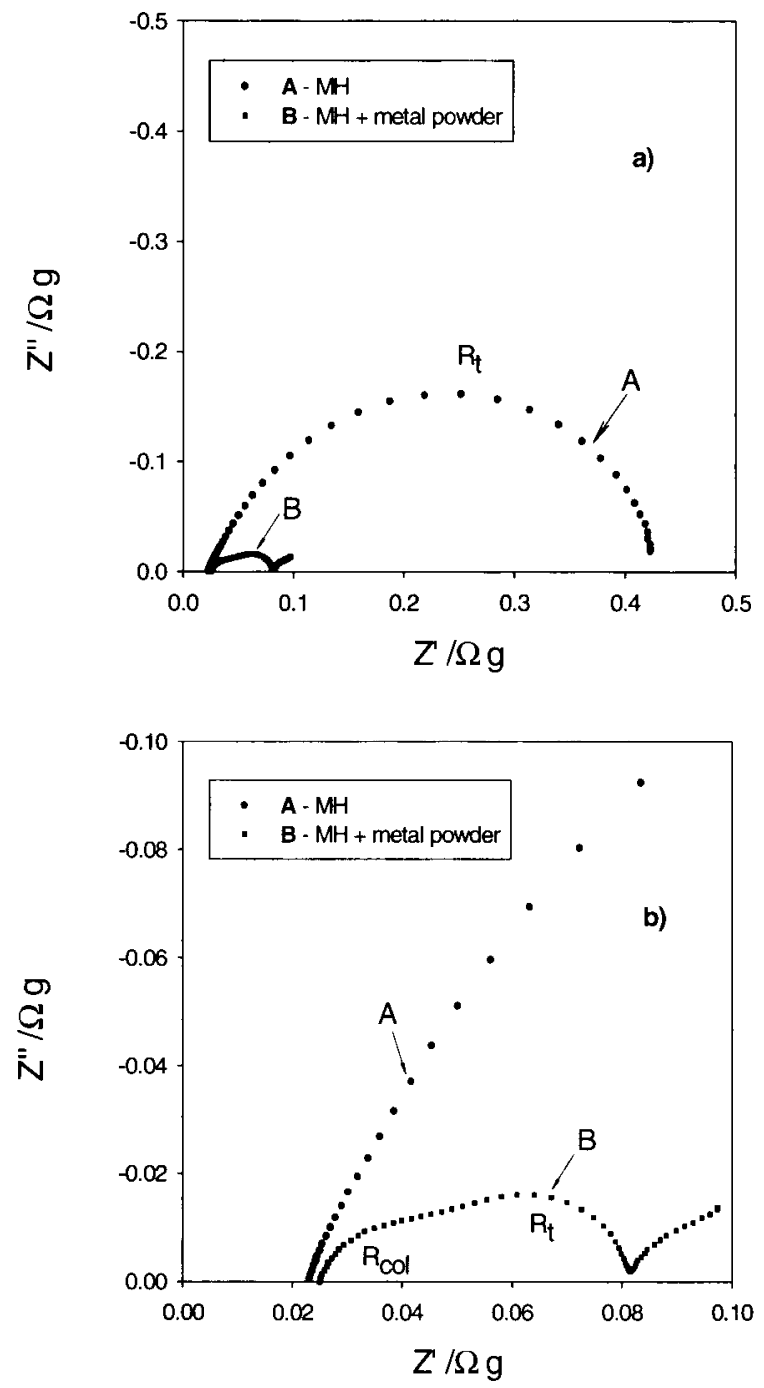

Fig. 1 a) A.c. impedance behaviour of $\mathrm{MH}$ electrode in $6 \mathrm{M} \mathrm{KOH}$, at RT and ca. $50 \%$ SOC (upon discharge at $\mathrm{C} / 10$ rate). b) As above, but high frequency region is shown. 

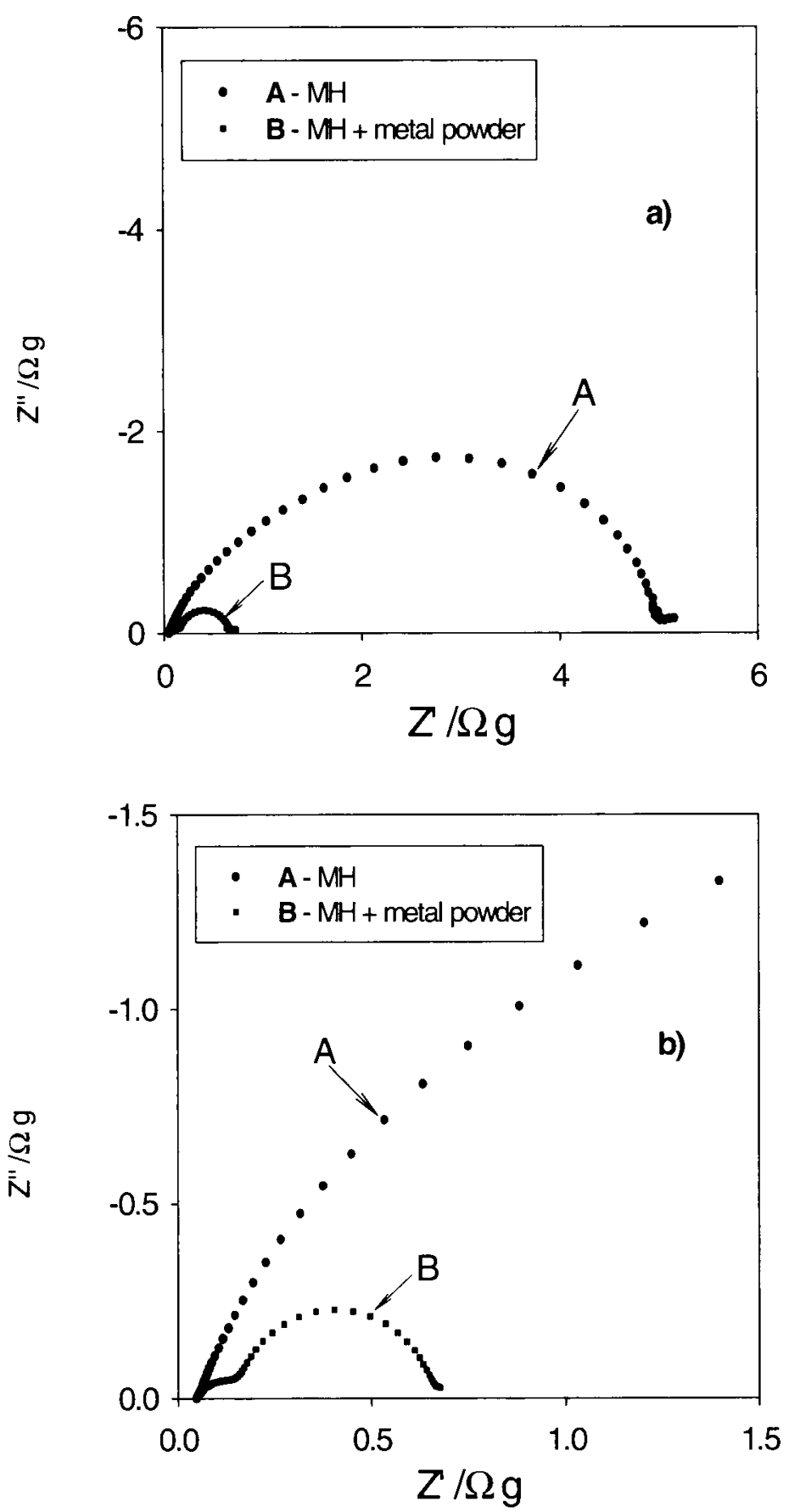

Fig. 2 a) A.c. impedance behaviour of $\mathrm{MH}$ electrode in $6 \mathrm{M} \mathrm{KOH}$, at $-25^{\circ} \mathrm{C}$ and ca. $50 \%$ SOC (upon discharge at $\mathrm{C} / 10$ rate). b) As above, but high frequency region is shown. 


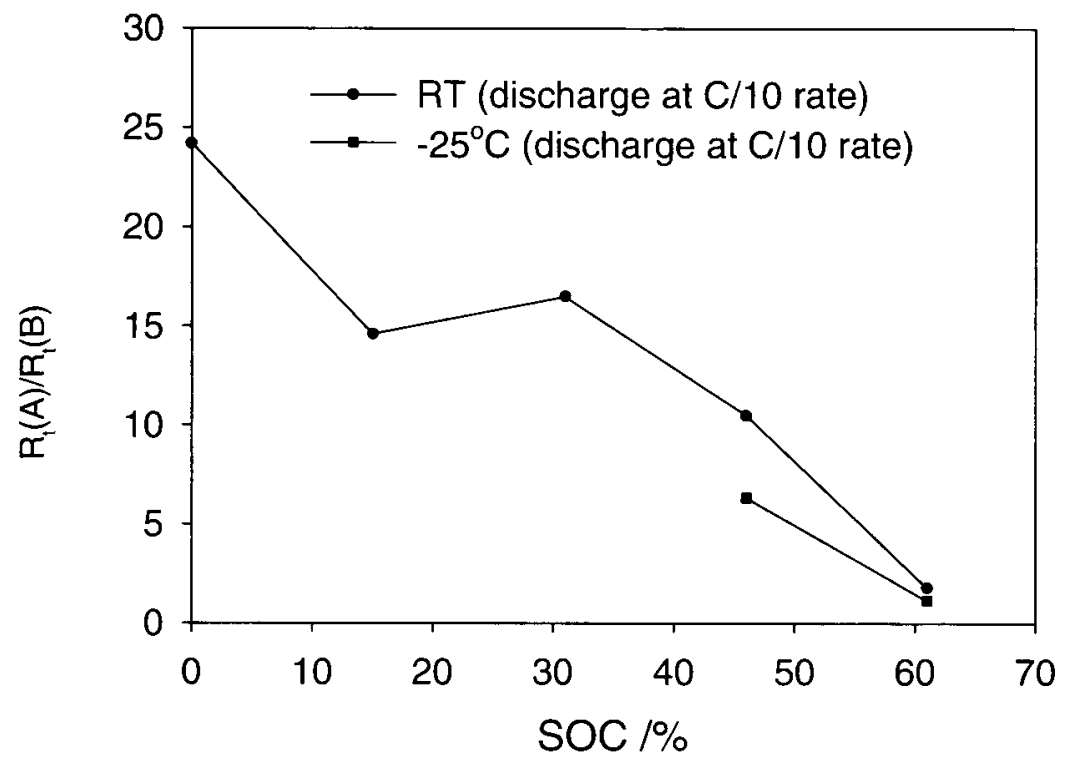

Fig. 3 Ratio of the charge-transfer resistance parameter for the MH electrode of composition A to that of B, as a function of the electrode's SOC.

\section{Supercapacitors-Complementary to Batteries Devices for Electrical Energy Storage}

Contrary to batteries, which store and deliver electrical energy chemically (by initiating and reversing chemical reactions), supercapacitors store energy by electrostatic way (see Figure 4 below). There are two types of supercapacitors: ad-species or redox (e.g. $\mathrm{Ru} /$ $\mathrm{RuO}_{2}$ system) and double-layer supercapacitors [14]. The former ones are based on utilization of faradaic charge-transfer reaction and its corresponding large pseudocapacitance $\left(\mathrm{C}_{\phi}\right)$ :

$$
C_{\phi}=\frac{\Delta q}{\Delta V} \quad\left(400-1,000 \mu \mathrm{F} / \mathrm{cm}^{2}\right)
$$

whereas the latter ones utilize the phenomenon of interphasial electrical double-layer. The electrical double-layer arises from the separation of ionic charges at the interfaces, between solid (usually metal) and ionic solutions (see Figure 5). Thus, supercapacitors consist of two separated interphasial double layers. Typical range for double-layer capacitance $\left(\mathrm{C}_{\mathrm{dd1}}\right)$ is $20-50 \mu \mathrm{F} / \mathrm{cm}^{2}$. 


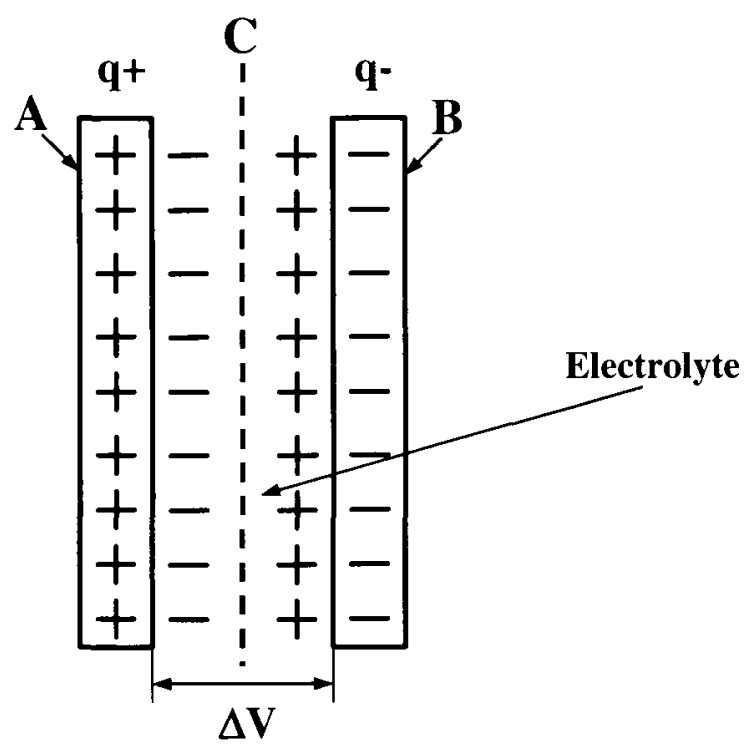

Fig. 4. Electrostatic way of electrical energy storage by supercapacitors, where:

A, B-positive and negative plates; $C$ - separator $\mathrm{q}^{-}, \mathrm{q}+-$ negative and positive charges; $\Delta \mathrm{V}$ - voltage between the plates

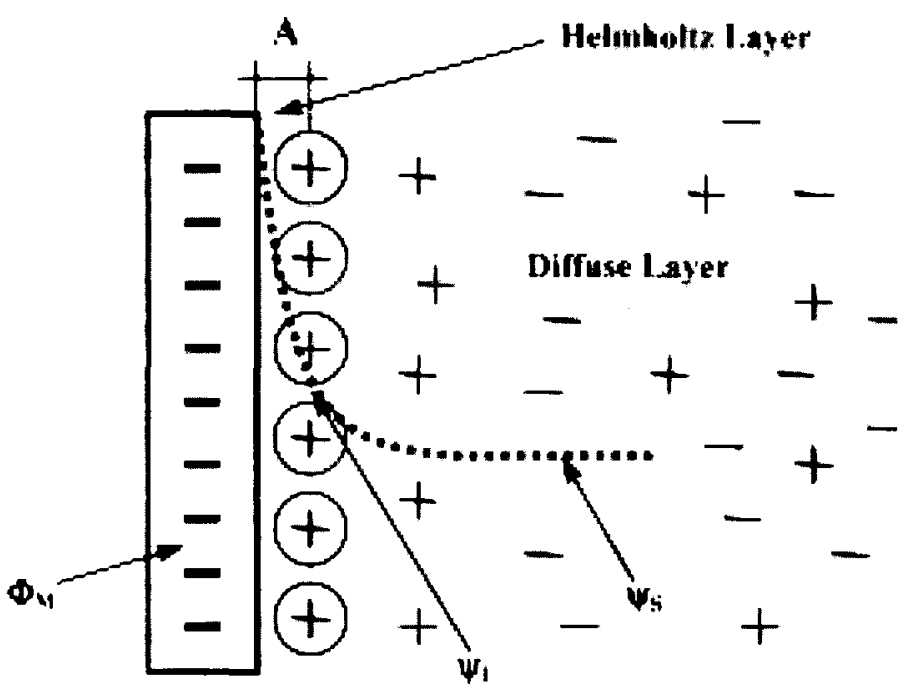

Fig. 5. Double-layer model proposed by Stern [15], where: $\psi_{1}$ - mean potential at $\mathrm{r}=\mathrm{A} ; \psi_{\mathrm{S}}$ - potential of the solution $\Phi_{M^{-}}$potential of the metal; A- distance of approach of ions to the metal (radius) 
Practical, carbon-based double-layer supercapacitors have found applications in HEV systems, as complementary to batteries devices for electrical energy storage. Activated carbon powders and fibres, carbon aerogels, glassy carbon and similar types of materials are inexpensive and non-toxic base materials for building such supercapacitors. Some of the characteristics for double-layer electrochemical capacitor devices are given below:

- Voltage $^{4}-1.4 \mathrm{~V}$ range in aqueous and $3.4-4.0 \mathrm{~V}$ in non-aqueous electrolytes

- Electrode surface area - 100-2,000 $\mathrm{m}^{2} / \mathrm{g}$

- Specific capacitance - 100-200F/g

- Discharge currents - over 200A

- Life cycle - more than $10^{6}$ recharges (practically indefinite)

Their major role in HEV systems is to power the electric engine of the hybrid power unit, when fast acceleration is needed. Main advantages of the supercapacitor device over a conventional battery is that they can undergo extremely high discharge currents and rates of recharging. They are also maintenance-free devices. In this respect, wide application of supercapacitors could effectively lower the cost of utilization of used battery units. However, supercapacitors are low energy density devices. Also, unlike for batteries, for an ideal supercapacitor, its voltage linearly decreases with discharged capacity (see Figure 6). In other words, electrochemical double-layer supercapacitors are typical complementary devices for electrical energy storage and cannot be considered as a complete battery replacement.

\section{Conclusions}

Recent development of hybrid-electric vehicles is a consequence of new environmental trends and regulations, as well as increasing concern about shrinkage of oil reserves. Nickel metal-hydride battery is a widely accepted energy storage device for HEV. One of the most significant problems of the NiMH system is poor low temperature characteristics of the metal hydride electrode. This performance can be significantly enhanced by addition of small amounts of metal powder catalysts into the $\mathrm{MH}$ mass (enhancement of the charge-transfer reaction).

However, poor electrode performance at low temperatures may also be due to other factors than the charge transfer or/and $\mathrm{H}$ diffusion processes. A strong possibility is that at very low temperatures there is effective blocking of active sites, especially within narrow pores, where

4 For high voltage demands, supercapacitors could be stacked in series. 
the reaction becomes suppressed as a result of local, high electrolytic resistance. Significantly reduced mobility of $\mathrm{H}_{2} \mathrm{O}$ at high discharge rates may possibly result in local freezing of oriented water molecules at the interface. Thus, it is suggested that further, specific aspects be considered, as follow:

- optimization of electrode's composition, with respect to the particle and pore size, and distribution

- prevention of local electrolyte freezing at low temperatures, by lowering its freezing point and increasing its intrinsic conductivity

Having a number of advantages over batteries, double-layer supercapacitors become an important system for electrical energy storage. Application of inexpensive, carbon powder-based double-layer supercapacitors into HEV and similar technologies, seems very promising.

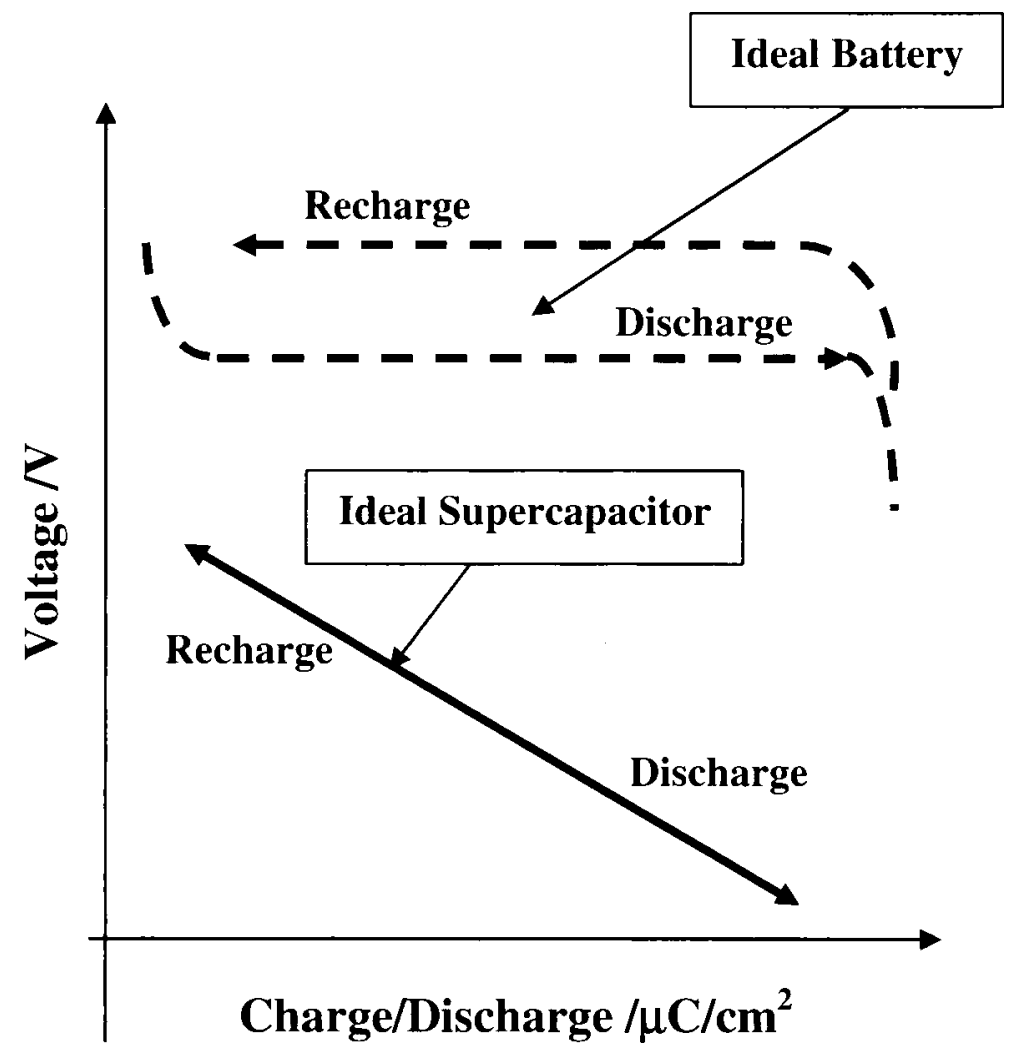

Fig. 6. Difference of discharge and recharge voltage characteristics for an ideal supercapacitor and a battery. 


\section{References}

CARRETTE L., FRIEDRICH K.A. and STIMMING U., 2001 Fuel Cells, 1, 5.

GIFFORD P., ADAMS J., CORRIGAN D. and VENKATESAN S., $1999 \mathrm{~J}$. Power Sources, 80,157

DHAR S.K., OVSHINSKY S.R., GIFFORD P.R., CORRIGAN D.A., FETCENKO M.A. and VENKATESAN S., 1997 J. Power Sources, 65, 1.

HONG K., 2001 J. Power Sources, 96, 85.

YUASA S., N. FUJIOKA, K. KANAMARU and TAKAHASHI O., 2001 Proceedings, EVS 18 , Berlin.

WANG C. et al., $2000-J$. Power Sources, 85, 212.

YUAN X. et al., $2001-J$. Alloys and Compounds, 316, 113.

KURIYAMA N. et al., 1993 - J. Alloys and Compounds, 201, 183.

REICHMAN B. et al., 1998 - Electrochemical Society Proceedings, vol. 15, 111.

VALOEN L.O. et al., $2002-J$. Alloys and Compounds, 330-332, 810.

VALOEN L.O. et al., 2000-16 - Electrochemical Society Proceedings, vol. 133.

MACDONALD J.R., 1990 - Electrochim. Acta, 35, 1483.

PAJKOSSY T., 1994, - J. Electroanal. Chem. 364, 111.

CONWAY B.E., 1999 - Electrochemical Supercapacitors, Plenum Press Co., New York.

BOCKRIS J.O'M. and REDDY A.K.N., 1970 - Modern Electrochemistry, vol.2, Plenum Press,

New York.

\section{Systemy Gromadzenia Energii Elektrycznej dla Pojazdów o Napędzie Hybrydowym - Nowy Koncept Motoryzacji}

\section{STRESZCZENIE}

Dynamiczny rozwój pojazdów o napędzie hybrydowym (spalinowo-elektrycznym) wymuszony został szybko zmieniającymi się przepisami w ochronie środowiska naturalnego oraz ciągła fluktuacją cen ropy naftowej. Baterie niklowo-wodorkowe (NiMH) stanowia podstawowe źródło stałe energii elektrycznej $w$ pojazdach tego typu. Jednym $\mathrm{z}$ najpoważniejszych problemów $\mathrm{w}$ systemach baterii NiMH jest kinetyka reakcji rozładowania elektrody wodorkowej $\mathrm{w}$ niskich temperaturach. Usprawnienie niskotemperaturowego zachowania baterii NiMH można uzyskać poprzez wprowadzenie niewielkich ilości dodatków katalizujących do masy $\mathrm{MH}$.

Opisane superkondensatory elektrochemiczne, oparte na wykorzystaniu pojemności podwójnej warstwy elektrycznej materiałów węglowych o dużej specyficznej powierzchni, znajdują zastosowanie jako uzupełniające źródła gromadzenia energii elektrycznej. Sa zazwyczaj stosowane w pojazdach hybrydowych równolegle $\mathrm{z}$ bateriami NiMH. 